\title{
LA IMAGINACIÓN ORGÁNICA Y SOBRENATURAL EN LA CRÍTICA LITERARIA COLOMBIANA DEL SIGLO $\mathbf{X I X}^{*}$
}

\author{
THE ORGANIC AND SUPERNATURAL IMAGINATION \\ IN NINETEENTH CENTURY COLOMBIAN LITERARY \\ CRITICISM
}

Camila Palacios Amézquita ${ }^{1}$

Artículo derivado de investigación sobre literatura y pensamiento colombiano del siglo XIX.

Cómo citar este artículo: PalaciosAmézquita, C. (2019). La imaginación orgánica y sobrenatural en la crítica literaria colombiana del siglo xIX. Estudios de Literatura Colombiana 44, pp. 13-30. DOI: https://doi.org/10.17533/udea.elc.n44a01

icpalaciosa@unal.edu.co

Universidad Nacional de Colombia, Sede Bogotá

Recibido: 15.08 .2018

Aprobado: 02.10.2018

Copyright: $@ 2019$ EstudiosdeLiteratura Colombiana. Este es un artículo de acceso abierto distribuido bajo los términos de la Licencia Creative Commons AtribuciónNo comercial - Compartir igual 4.0 Internacional
Resumen: las tensiones ideológicas que marcan el siglo XIX se evidencian en toda clase de discursos, entre ellos el de la crítica literaria. A pesar de las diferencias manifiestas entre los ejercicios críticos de algunos autores de la época, puede hablarse de ejes que unifican sus trabajos: el pensamiento positivista y el pensamiento religioso, notoriamente católico, que encuentran lugar en la imaginación orgánica y en la imaginación sobrenatural, respectivamente. A lo largo de este texto se analizarán las imágenes que configuran las líneas de pensamiento mencionadas de acuerdo con algunas de las problemáticas literarias que abordan.

Palabras clave: crítica literaria colombiana; imagen crítica; positivismo; imaginación orgánica; imaginación sobrenatural.

\begin{abstract}
The ideological tensions that mark the nineteenth century are evident in all kinds of discourses, including the literary criticism. Despite the obvious differences between the critical exercises of some authors of the time, it is possible to talk about axes that unify their works: positivist thought and religious thought; notoriously catholic, which find place in the organic imagination and in the supernatural imagination, respectively. Throughout this text, the images that make up the mentioned lines of thought will be analyzed according to some of the literary problems that they address.
\end{abstract}

Keywords: Colombian literary criticism; Critical image; Positivism; Organic imagination; Supernatural imagination. 
La situación de Colombia en el siglo XIX responde a una tensión ideológica constante que se expone y desarrolla en múltiples discursos, incluyendo la literatura. Novelas, ensayos, textos críticos, poesía, crónicas, artículos de periódicos y otros tipos de textos aparecen profundamente marcados por la diferencia. En el ejercicio crítico de la Colombia del siglo XIX, ${ }^{1}$ una de las diferencias más notables es la variedad de tipologías textuales que se usaron para llevar a cabo las reflexiones sobre la literatura. Como señala Jiménez (2009), es posible encontrar la configuración de un pensamiento crítico y literario tanto en las traducciones y estudios filológicos de Miguel A. Caro como en los artículos de prensa y los momentos ensayísticos en De sobremesa, de José Asunción Silva, pasando por las semblanzas biográficas de José María Samper. De igual manera, hay diferencias entre lo que los autores pensaban que debía ser la crítica. Basta ver cómo se contraponen las perspectivas de Caro con las de Silva y Sanín Cano, quienes representan para Jiménez los dos polos opuestos a partir de cuya fluctuación avanza la literatura colombiana.

Miguel Antonio Caro, por un lado, escribió, en sus Estudios virgilianos (1985), que la crítica literaria debía cimentarse en una crítica gramatical y debía ostentar un carácter estético, que "ora abrazando el conjunto y ora descendiendo a los pormenores, estudi[e] el espíritu de la composición y señal[e] los aciertos y errores, las bellezas e imperfecciones" (p. 340). Caro rastrea el nacimiento de la crítica hasta la Antigua Grecia y la entiende como disciplina emancipada recientemente que "se ostenta adulta en ensayos y estudios especiales" (p. 340). Este autor se inclina a una definición de crítica a partir de ideales neoclásicos como la sabiduría del que escribe y su buen gusto, y da tanta importancia a la función valorativa de la crítica como a la función analítica. Un crítico profundo, para Caro, debe ser ante todo un hombre de fe, un erudito, debe estar provisto de conocimientos auxiliares y demostrar que es poseedor de diversas facultades. Además, Caro ve en la crítica una herramienta valiosa para una época llena de "influencias exageradas" y, por eso, alienta el cultivo de esa "noble facultad" (p. 438).

Por otro lado, la propuesta de Silva se sitúa del lado de la función

Es necesario aclarar que no hablaré de la crítica como género, sino como ejercicio, pues, siguiendo a David Jiménez (2009), si bien en el siglo XIX el discurso crítico empieza apenas a formarse, no consigue institucionalizarse: ni en ese momento "ni en el presente se han reunido las condiciones propicias para la formación de un grupo profesional de críticos literarios. Sin embargo, la actividad crítica ha sido realizada con logros desiguales pero no sin cierta continuidad hasta hoy" (p. 32). 
analítica, orientada a la historicidad, al contexto y a la tradición, y se opone a la valorativa. Así, Silva (1888) señala dos tipos de crítica, aunque él mismo no se sienta parte de ninguno: la crítica seria y la ligera. Esta última exige que se 'rasguñe' la obra de arte, para hacer reír al lector, y una atención de microscopio a los defectos: la crítica ligera carece de dificultad. En cambio, la crítica seria, que a su mirada era la que debía hacerse, "busca los orígenes lejanos de una obra, [...] la aprecia como expresión del pensamiento dominante en cierta época [...], investiga su influencia en el desarrollo de la que le sigue" (n.p.) y es un trabajo arduo. Ese interés histórico también está implícito en los Estudios virgilianos de Caro.

Sanín Cano (1934) señala, en "La crítica por jurados", que la misión del crítico nunca ha sido envidiable: "Brotaban a su paso enemigos irreconciliables a la manera en que nacen los fresales cuando pasa por los bosques de los Andes el hacha del colono que tala los árboles" (p. 145). El crítico se ve en una encrucijada entre el hacer una alabanza exagerada o un estudio desapasionado, en la que corre el riesgo, en cualquier caso, de perder un amigo o de ser tildado de sospechoso. Además, dice Sanín Cano, solía ser necesario,

[...] para ejercer la profesión de crítico, estudiar antes que literatura, filosofía, ciencias ocultas y lenguas orientales, un poco de esgrima y manejo de armas de fuego. [...] bastaba por lo general haber leído a Alejandro Dumas padre, y tener nociones de la diferencia que existe entre Paul de Kock [...] y Emilio Zola [...]. Bastaba esto, siempre que el manejo del sable y la pistola hubieran precedido a toda otra disciplina, de las disciplinas gentiles (p. 147).

En el prólogo que escribió a las Obras completas de Juan de Dios Uribe, Sanín Cano (2013) dice del Indio - escritor liberal, periodista y polemista antioqueño - que tuvo vocación manifiesta de crítico, y enumera una serie de características que podemos tomar como ideales en aquel que ejerce dicha labor: "gusto firme, vastas y bien digeridas lecturas, juicio independiente, admiración documentada de lo bello donde quiera que lo encontrase" (p. 48). Sin embargo, Sanín Cano le critica a Uribe su temperamento de luchador: la preferencia que otorgaba al uso del sable y la pistola, por encima del ejercicio de una crítica analítica. En resumen, en Sanín Cano están planteadas como esenciales las tres funciones de la crítica: la analítica, que propone explícitamente, la interpretativa, al hablar de un juicio independiente, y la valorativa, al sugerir la importancia de un gusto firme.

Hay, todavía, otra diferencia importante que apunta a los contenidos y al tratamiento que se hace de ellos. Jiménez identifica tres vías en las que se ramifica el ejercicio crítico en el siglo XIX: la dogmática, la 
impresionista y la cientifista. Pedro Aullón de Haro (1994), algunos años después, en "Epistemología de la teoría y la crítica de la literatura", señala la importancia de diferenciar entre la crítica militante, la impresionista y la científico-humanística. Las dos primeras son producciones "libremente reflexivas": la militante es "polemizadora y partidista", piénsese en Caro o en el Indio Uribe; la impresionista es "intuitiva y asistemática" (p. 19) y suele presentarse como ensayo - Samper y Silva podrían leerse desde esa perspectiva - . Por otro lado, la crítica científico-humanística es "la reflexión metodológica sobre una estructura objetiva que se describe a partir de la constitución y relaciones sistemáticas [...] del texto literario respecto de sí propio u otros sistemas" (p. 21). Este tipo de crítica relaciona la filología y la filosofía como ejes del ejercicio y recuerda inevitablemente las Divagaciones filológicas de Sanín Cano.

A pesar de estas diferencias que he señalado, que en principio podrían parecer rígidas e irresolubles, hay, en la crítica de Caro, Uribe, Samper, Silva y Sanín Cano, ejes unificadores que se manifiestan en las imágenes y metáforas que construyen en su ejercicio como críticos. El primero de estos ejes es la influencia del pensamiento cientificista en el siglo XIX que se evidencia en la configuración de una imaginación orgánica; el segundo eje tiene que ver con las reminiscencias y la fuerza que aún a mitad del siglo XIX mantiene el imaginario de la religión católica y que se manifiesta en una ideación sobrenatural. Hablemos, pues, de los ejes.

\section{Imaginación orgánica y científica}

A partir de la segunda mitad del siglo XIX, la mentalidad científica en Europa y América fue adquiriendo cada vez más terreno y la idea de progreso se constituyó como idea rectora de la modernidad y la Ilustración. Desde comienzos del siglo tuvo lugar, siguiendo a González Echevarría (1998), el segundo descubrimiento de América:

Si los primeros descubridores y colonizadores se apropiaron de América Latina por medio del discurso jurídico, estos nuevos conquistadores lo hicieron con ayuda del discurso científico, lo que les permitió volver a dar nombre (como si fuera la primera vez) a la flora y fauna del Nuevo Mundo (p. 141).

El discurso científico propuesto en los relatos de viajeros europeos pronto se erigió como el discurso por excelencia sobre la realidad latinoamericana y, según la tesis de González Echevarría, empezó a influenciar nuestras narrativas, ficcionales o no. Además, el interés que despertó la ciencia moderna determinó el crecimiento de una corriente de 
pensamiento que, si bien surgió en las ciencias naturales, pronto se extendió a la política, el arte y la literatura. El positivismo adquirió diferentes matices en cada uno de los países en que fue importante, pero mantuvo la idea del método de las ciencias naturales como aquel que permitía una aproximación al conocimiento verdadero.

En Colombia, a pesar de la ensañada lucha partidista, "puede afirmarse que las ideas positivistas fueron determinantes tanto para liberales como para conservadores, tanto para quienes estaban prestos a atacarlas y a desmontar sus principios como para aquellos que las defendían" (Arango y Fernández, 2011, p. 44). No importaba el bando desde el cual se emitiera el discurso: ni siquiera la escritura de Miguel Antonio Caro (el mayor enemigo del positivismo según Leonardo Tovar) quedó sin mácula después de la absolutización de esta corriente de pensamiento.

En Fundamentos estéticos de la crítica literaria en Colombia, Sofía Arango y Carlos Fernández (2011) ven en el positivismo una de las cuatro corrientes importantes que subyacen al ejercicio crítico en la época. En el apartado que dedican a esta corriente de pensamiento, los autores citan un fragmento de Conceptos de crítica literaria, de Wellek (1968), en el que el autor menciona algunas de las maneras en que se hizo uso de los planteamientos del positivismo en la crítica literaria en el siglo XIX y que convirtieron a los estudiosos de la literatura en "científicos, o más bien, paracientíficos" (citado en Arango y Fernández, 2011, p. 45). Wellek encuentra que, siempre y cuando se fundamentara lo propuesto sobre lo cronológico y se atendiera al origen y causas de los fenómenos literarios, era justificable cualquier clase de relación. Asimismo, dice el autor, hubo quienes intentaron trabajar con los métodos cuantitativos de la ciencia como la estadística y los gráficos, a tal punto que "finalmente, un grupo más ambicioso hizo un ensayo, a gran escala, para emplear los conceptos biológicos en el delineamiento de la evolución de la literatura" (p. 45). Arango y Fernández aseguran que en la crítica que se hace en Colombia en el siglo XIX y parte del xx hay un frecuente uso de esa terminología. Es en ese sentido en el que propongo una lectura de las metáforas e imágenes usadas por los críticos de la época, que configuran una imaginación orgánica que aborda diversos temas y los une por encima de sus discrepancias ideológicas y de su escogencia de una u otra tipología textual para darle forma a su pensamiento crítico.

La tradición, y las discusiones que alrededor de ella se tejen, es ampliamente tratada en la crítica colombiana del siglo XIX bajo la 
terminología científica que estaba en boga. Hay dos imágenes predominantes en el tratamiento de este asunto; una es la del organismo vegetal y la otra es la del agua que, a pesar de no estar viva en sí misma, es fundamental para la subsistencia de todas las formas de vida conocidas.

Para Juan de Dios Uribe (2013), "los mismos grandes hombres que depositaron el grano de la revolución política pusieron también en el surco la semilla de la revolución literaria" (p. 92). Resulta interesante que en la imagen de la semilla está contenido todo lo que el organismo podría llegar a ser y, aun así, sin agua, sin sol, nunca crecería. En este caso, la revolución literaria se alimenta de los nutrientes que le brinda el pensamiento liberal: la búsqueda de la verdad, el sostenimiento de la libertad y la rehabilitación de la América (p. 93). José María Samper (1953), en su "Discurso de recepción en la Academia colombiana", hace uso de una imagen parecida al hablar de la dignidad de ciertos asuntos que merecen ser tratados por escritores ingeniosos y a los cuales él apenas podría aportar desflorando el "ameno campo" que los escritores que idealiza "podrían beneficiar cosechando con segura mano frutos bien sazonados y abundantes" (p. 169). Aunque Samper se presenta como un hombre hecho de contradicciones, se podría pensar en ese campo como el resultado de la semilla de revolución literaria de la que habla el Indio Uribe. En "Bastiat y Bentham", Caro (1951a) también utiliza la imagen de la cosecha, pero con él podemos estar seguros de que ella no proviene de una revolución. Su campo es uno sembrado y sostenido por los mandamientos de la religión católica (tronco y raíz), que dan lugar a provechosos frutos. Sin embargo, para Caro, Bentham va a ese campo y le arranca al árbol sus hojas, ramas, flores y raíces, y espera, todavía, recoger frutos. La crítica en esa imagen es al positivismo utilitarista de Bentham y se sostiene en una postura rígida y conservadora que ve la necesidad de regirse por los preceptos de la religión católica, sin la cual nada crece ni ningún fruto madura.

De la misma manera, el poeta necesita beber de las corrientes de la tradición para crear su obra a partir y dentro de ella. Tal cosa dice Caro de Virgilio y allí se asienta una discusión importante de la época que trata de la pertinencia de recibir influencias extranjeras. Caro era un hispanófilo que consideraba fundamental la continuación de la influencia cultural de España en América y que muchas veces hablaba de las fuentes francesas e inglesas como perniciosas; para él, había que evitar a toda costa "contaminarnos bebiendo el veneno esparcido en libros de autores fementidos y malévolos" 
(Caro, 1951a. p. 79). En contraste, vale la pena ver lo que pensaba el Indio Uribe de las influencias extranjeras. En "La lira nueva", Uribe (2013) habla de Víctor Hugo como una boa inmensa "que fascina y se traga a los enamorados de su abismo". Dice también que

[...] se le debe estudiar y traducir, pero no imitar [...] Quien se encuentre con poderosas fuerzas, antes de caer en el gran molde, debe formar la paralela del maestro; de otro modo solo logrará ser una chispa de su inmortal hoguera (p. 300).

Es notable que, no por apoyar la influencia francesa, el crítico fomente su imitación, antes bien, hay una invitación a posicionarse críticamente frente a la escritura del extranjero y una exhortación a ser original, a construir grandeza en las formas propias. Si Caro, por un lado, parece ubicarse en el papel del censor que lee y determina que una obra es venenosa y, por lo tanto, no debería ser leída, el Indio Uribe incita el estudio, la traducción, la lectura individual, pero crítica, que cada cual debe hacer de obras y autores de cualquier latitud. Similar a la del Indio es la actitud de Sanín Cano (1934) en "De lo exótico" que, hablando de la que debería ser la grande ocupación del hombre de letras ("vivificar regiones estériles o aletargadas de su cerebro"), pareciera contestarle a Caro:

Los ambientes diversos, los heredamientos acumulados en razas vigorosas les van dando a las letras savia rica, que algunos no se atreven a llamar sana. Sería injusticia no explotar una forma de arte nuevo solamente porque salió de una alma eslava (p. 232).

También Samper (1953) toma posición frente a la discusión sobre la tradición y las influencias. En el mismo discurso que hizo para la recepción en la Academia colombiana, se compara con una onda que, después de perderse entre la maleza, se confunde con el "caudal clarísimo, apacible y hábilmente encauzado" (p. 167) que han compuesto los señores de la academia durante quince años; Samper llama la atención sobre su pequeñez como individuo en comparación al inmenso valor de la caudalosa tradición.

Pero si la tradición se asemeja a un caudal, como dice Samper, también corre el riesgo de estancarse. Así lo señala al hablar de la literatura colombiana antes de 1842, que "parecía estar muerta entre nosotros, o por lo menos estancada, como un lago sin renovado caudal de aguas frescas y sin fácil salida" (p. 170). El autor reconoce que ha habido una preponderancia de la política sobre la literatura e intuye un problema que, a pesar de su importancia, poco trata en su obra, y que estará mucho más cercano a las discusiones de los modernistas como Silva y Sanín Cano: se trata de la autonomía de la literatura y del arte. 
De cualquier modo, después de ese estancamiento, Samper (1953) habla de las razones del reavivamiento de las letras y del nacimiento de una literatura joven, sí, pero ya completamente colombiana en 1850. Para Samper, es el soplo de algunos pensadores sobre las cenizas lo que permite que el fuego casi extinto se avive y se propague, que el alma y la literatura se electricen y que sea posible la "abundantísima cosecha de producciones poéticas y literarias" (p. 181). Sin embargo, en una línea de pensamiento tan romántica como la de Samper, esa no podría ser explicación suficiente. Por ello, el autor hace ver en las influencias apenas el empujón que permite al genio poético revivir, crecer, desbordarse:

A la manera que un arroyo, apacible en sus fuentes y estancado después por fuertes obstáculos en largo trecho, se convierte al cabo en torrente caudaloso cuando de súbito se le apartan los diques que lo contenían, [...] el genio poético [...] estalló por doquiera, que tal es la expresión adecuada, y se difundió, desbordado también, como una fuerza que había bregado por abrirse paso y repentinamente se sentía libre (Samper, 1953, p. 180).

Tal vez sea demasiado arriesgado sugerir que los diques y los obstáculos de los que habla Samper hayan sido esa misma influencia española que él defiende. Sin embargo, es evidente que este autor ve en la literatura colombiana una robustez mayor que la que ostenta la literatura española. En ese sentido se asemeja su pensamiento al del Indio Uribe: evitar la imitación y dejar desbordar el genio poético en estas tierras es lo que, finalmente, permite que se hable de una literatura colombiana joven, pero sólida. Además de eso, en esta cita sale a la luz una interesante muestra de la convivencia entre romanticismo y positivismo. Este genio que estalla y se desborda es, en ese surgimiento, indudablemente romántico. Sin embargo, como dice Samper, es producto de los elementos físicos y morales de la sociedad (lo que no es más que el desarrollo de teoría del medio de Taine).

Silva (1894) elabora, respecto de las cuestiones de la tradición, la evolución de la literatura y las influencias que he venido tratando, la siguiente imagen:

[...] la labor del espíritu humano no se interrumpe jamás: de cada colmena las abejas toman distintas direcciones y van a dejar el rastro de su miel en las múltiples flores de los campos. Así los espíritus con cada descubrimiento, con cada verdad [...]. La escuela moderna en literatura se dividió y subdividió prontamente, adoptando los diferentes grupos otras tantas denominaciones según el matiz literario que predominaba en sus obras; de ahí los nombres de estilistas, formistas, fantasistas, impasibles, realistas que adoptaron los que no tenían asiento en el cenáculo aristocrático (n.p.). 
La atención de Silva no recae ya en la planta, en la cosecha o en el caudal. Silva ve con claridad aquello de la planta que, aun estando toda ella contenida desde la semilla, no puede crecer ni vivir sin el agua y sin el sol, sin las abejas polinizadoras. Aquí, entonces, está implícita la idea del poeta y la creación poética como organismos vegetales que necesitan de factores externos para sobrevivir y para alcanzar su madurez. El mejor ejemplo de esto lo da Silva (1894) cuando, hablando de la literatura española y su evolución distinta a la francesa, se pregunta qué pensar de "un escritor en lengua castellana, por añadidura hispanoamericano, y todavía más, nicaragüense, que se nos presenta vestido con las prendas de un parnasiano degenerado en decadente, sin dejar de ser por eso de pura cepa española" (n.p.). Darío es para Silva planta exótica entre la literatura hispanoamericana, y lo es porque, aun siendo nicaragüense, sus influencias, su sol, su lluvia, sus abejas fueron los decadentes franceses; así, Darío es americano en la figura y francés en espíritu.

Si bien las imágenes y la ideación de lo orgánico están presentes en los autores mencionados hasta ahora, ninguno de ellos consigue desarrollarlas tan profunda y ampliamente como Sanín Cano. En "Del estilo", compara la clasificación del estilo en grave, florido, austero, etc., con las clasificaciones de artificial y natural en el reino vegetal:

Tournefort y Cuvier dividieron las plantas, teniendo en cuenta la forma y dimensiones del tallo, el número de los estambres y carpelos y su disposición en la corola, ó el tamaño relativo de aquellos. Esta clasificación basada en la apariencia de los objetos, era inadecuada. Ateniéndose a ella era menester colocar en grupos idénticos plantas que no tenían ni los más leves rasgos de semejanza, y al propio tiempo separar otras que, aunque con diverso número de órganos masculinos, sorprendían al botánico con la semejanza que ostentaban, considerados otros caracteres. Sucedía también que esas señales adoptadas para clasificar un vegetal no eran permanentes (Sanín Cano, 1890, p. 16).

Para Sanín Cano, basar la clasificación en el uso o abuso de los adjetivos de un autor, en lo "pomposo ó severo de su vocabulario, es proceder artificialmente" (p. 16), igual que basarse en la apariencia de las plantas para clasificarlas sin tener en cuenta lo verdaderamente distintivo y característico que tienen. Además, el problema en la clasificación de un estilo resulta una cuestión subjetiva que obedece a las formas como cada quien organiza mentalmente lo que observa. Para explicar esto, Sanín Cano parafrasea a Zola, quien habla de la censura que se hace a los novelistas modernos a causa de la abundancia de los detalles, y elabora un ejemplo parecido al que refiere del francés. Dos personas ven el cielo y, aunque ambas tienen desarrolladas las facultades de observación, una ve las cosas 
naturalmente: "todo le aparece según es su verdadero tamaño, y en la posición relativa que ocupa. Los colores, ella es muy capaz de percibirlos hasta en sus degradaciones más tenues" (p. 18). La otra persona ve primero el contraste: "percibe los colores mucho mejor cuando están combinados en grupos disonantes, y si no están puestos de esa manera, ella los relaciona de tal modo, que el contraste se le imponga" (p. 18). Las formas también las ve en sus diferencias. La conclusión de Sanín Cano es que ambas personas tienen estilo - $\mathrm{y}$ facultades de observación diferentes-, pero uno es natural y el otro reflejo, según la formación de ideas de cada cual. El estilo se vuelve un asunto central en tanto empieza a transformarse notablemente a finales del siglo XIX. Sanín Cano intuye que el estilo de su tiempo cambiará y se hará obsoleto: para los escritores que vendrán, el adjetivo de moda "a lo sumo será un elemento biológico que les sirva para explicar la hinchazón crónica de que adolece mucha parte de la producción contemporánea” (p. 25).

Quizá lo más interesante de la crítica de Sanín Cano es que teje la imaginación orgánica que configura alrededor del análisis de los métodos para el estudio de la literatura. En la nota inicial de Letras nacionales, Sanín Cano habla de la relación entre el genio literario y su medio, y examina dos perspectivas de otros autores al respecto. Para uno de ellos, Taine, si se conoce el ambiente, la raza y el momento en el que alguien escribe, puede conocerse la obra y fijar la personalidad del autor. Para el otro, Jorge Brandes, son las obras del autor las que permiten el estudio del carácter, inteligencia y nivel espiritual del que las escribe. Sanín Cano (1944) concilia ambas opiniones y explica por qué. "El naturalista, por ejemplo, puede, examinando el fémur de una especie desaparecida, deducir todas las apariencias del esqueleto y aún precisar el medio y las costumbres de la criatura" (p. 8). Este sería un método análogo al de Brandes. Por otro lado, el método de Taine para el estudio de la literatura sería análogo al del científico que, al estudiar el medio, el género de alimentación de un ave, sus costumbres, etc., puede entender el funcionamiento de su "canal digestivo y la forma de sus miembros prensiles" (p. 8). Transpuesta la analogía al estudio de un autor, Sanín Cano diría que es importante conocer de su vida, historia y costumbres "para formarnos una idea clara y documentada de su personalidad y de su valor literario" ( $p$. 8). Pero la obra por sí sola también puede ayudar a valorar los talentos del escritor, a saber cosas de su vida y de la época en que vivió.

Continuando con lo que ha dicho, Sanín Cano (1944) afirma que en la astronomía y la paleontología hay ejemplos de lo que hace la crítica con 
su objeto de estudio. En cuanto a la astronomía, llama la atención sobre la lectura de las leyes de la gravitación a partir de las cuales Le Verrier descubrió Neptuno - "los planetas, en el recorrido de sus órbitas, ejercen perturbaciones sobre las de sus compañeros y reciben de ellos las mismas influencias". (p. 9) - En cuanto a la paleontología, habla de cómo Osborn, atendiendo al rumbo de las masas de hielo, concluyó que "ciertas especies de animales, en su curso para escapar de los fríos intolerables causados por la invasión del hielo en el Asia central han debido acumularse en un punto del desierto de Obi” (p. 9); en ese punto el mar les habría cerrado el camino. Científicos que siguieron esas indicaciones encontraron allí los restos.

"Hay todavía más semejanzas", dice Sanín Cano, para empezar a hablar de un pedazo de esquista pizarrosa que tiene en su mesa. En la esquista, que se separa en lajas con facilidad, hay huellas de un caracol marino,

A veces entre dos lajas queda el molde perfecto de un molusco que perdió allí la vida [...] Con el tiempo la piedra se absorbió todo el organismo animal y no vino a quedar más que la huella de sus formas (p. 9).

Para saber cómo era ese animal, continúa Sanín Cano, solo habría que llenar el molde de cera y dejarla endurecer. La labor del naturalista que estudia un hueso para conocer al organismo al que este perteneció; el científico que estudia el medio ambiente y las costumbres del organismo buscando entenderlo; el astrónomo que descubre en los movimientos orbitales la existencia de otro planeta; el paleontólogo que halla, estudiando el medio, el punto en el que se extinguió una especie; el geólogo que en las rocas encuentra la posibilidad de reconstruir frente a sí todo el espectáculo de la vida pasada. Todas estas imágenes apuntan a explicar una única cosa: “el poeta, el novelista, el autor de dramas deja con sus obras, estampada en la enorme cristalización de ideas, formas y sentimientos, que es una época literaria, su figura intelectual claramente diseñada" (p. 9).

Además del interés por la literatura y el medio en el que surge, Sanín Cano también discurre en torno al genio natural y al talento. Hablando del Indio Uribe, dice que era un prosista dueño y conocedor de su instrumento y que no daba "la impresión del jardín erudito sino de la fronda al natural acomodada al clima y la bondadosa feracidad del suelo" (Sanín Cano, 2013, p. 43). El jardín y la selva fueron imágenes que utilizaron también los poetas románticos para hablar de la génesis de la invención poética. Aunque Sanín Cano no utiliza las palabras genio y talento, se puede deducir de su analogía a qué se está refiriendo. En contraposición, el Indio Uribe, que sí habla 
explícitamente del talento, parece entender por ello algo mucho más cercano a la selva del genio que al jardín de la erudición:

El talento es una fuerza esparcida debajo de los cráneos, pero que se manifiesta en sus obras con la misma desigualdad con que las fuerzas interiores del planeta se revelan en la superficie. También tiene la inteligencia montañas, colinas, valles, pozos y abismos (p. 297).

El hecho de que lo que el Indio llama talento se manifieste de forma desigual permite pensar que no hay un control del poeta sobre la obra, ni esta es resultado del laborioso trabajo del jardinero. Al contrario: todas las fuerzas interiores del poeta, del planeta, se manifiestan como poder creador y autosuficiente, orgánico, cíclico, sin que la consciencia del ser humano lo pueda evitar o cambiar.

\section{Imaginación sobrenatural}

Hasta aquí he puesto en evidencia la influencia de las ideas positivistas del siglo XIX en la configuración de una imaginería orgánica y científica en algunos escritos críticos de la época. Sin embargo, por más acogida que haya tenido esta corriente de pensamiento, la religión católica y, sobre todo, la imaginación sobrenatural que alrededor de ella se tejía siguieron ostentando su autoridad e influyeron, también, en la construcción de imágenes en la crítica literaria. Podría hablarse de reminiscencias de ese pensamiento religioso en el planteamiento de ciertos asuntos que tienen que ver con la psicología de la invención poética. Por supuesto, en un escritor como Caro no se trata de ello, pues el pensamiento católico atraviesa toda su obra. Algo parecido pasa con Samper, en quien "[...] confluyen todas las contradicciones de la época, sin alcanzar una síntesis" (Jiménez, 2009, p. 35). En los demás escritores que escogí para esta investigación —Uribe, Silva y Sanín Cano-, el pensamiento religioso ya está mediado por procesos de secularización. Sanín Cano, en su afán de separar los motivos religiosos y políticos del análisis estético de la literatura, propone la discusión sobre la autonomía del arte a finales del siglo XIX. El Indio Uribe, por su parte, reconoce la fuerza de la religión católica en su época, pero prevé su debilitamiento y, en "Juicio crítico", habla de Dios como un ente ficticio, muerto ya, que la religión todavía intenta proteger:

[...] la poesía católica va por el mundo en marcha amenazadora, a la manera de aquel gran Titán Polifemo, de quien dice Virgilio que hacía temblar las montañas a su paso, se apoyaba en el pino más crecido de la selva y las olas furiosas del Océano apenas alcanzaban a mojar con espuma su cintura; pero como el Titán de la Eneida, el Catolicismo es ciego, y día vendrá en que [...] no sepa del camino ni pueda parar los golpes del enemigo (Uribe, 2013, p. 99). 
Cabe resaltar que las imágenes que usan los escritores dan cuenta de una imaginación alrededor de la religión que no ha sido completamente superada; no obstante, esta imaginación adquirirá unos matices que le permitirán ir más allá de la figuración de Dios como proveedor de la gracia poética. En "La religión y la poesía", Caro (1951b) achaca a Víctor Hugo un carácter indeciso y una conciencia angustiada que le hacen "canta(r) los duendes y las hadas, y agita(r) el kaleidoscopio de su vocabulario poético, produciendo diversidad de figuras y colores" (p. 386), o sea, obras como Las Orientales. Para Caro, esto es pseudopoesía que pone en evidencia un pensamiento sin rumbo, ideación llamativa pero vacía; en contra de esto, para hacer verdadera poesía, el poeta debe haber "mudado de dirección, renunciando a las inspiraciones de duendes bellacos y traviesos, reconcentrándose en su conciencia, y buscando allí luz y vida en las reminiscencias de su juventud" (p. 388). Duendes y hadas no son vistos por Caro como portadores de la gracia ni la inspiración, antes bien, son seres que hay que despreciar y alejar por el propio bien, pues impiden al poeta salir de la angustia y lo llevan por un camino colorido pero peligroso. Caro dice, en Estudios Virgilianos, que el genio poético no vive sino en el corazón que afirma a Dios por encima de todas las cosas, naturales y sobrenaturales.

El genio, dice Caro (1985), el poeta de primer orden, tiene, además de la fertilidad de la mente, unas características que lo distinguen entre los demás: “[...] la inteligencia de las cosas invisibles, la participación de la conciencia en las ocultas miras providenciales que se mezclan a las cosas de los hombres; [...] el conocimiento del corazón humano [...] y por último el fino tacto" (p. 88); o sea, dice el autor, inspiración, sentimiento y gusto. La inspiración nace, continúa Caro, de una visión sobrenatural que hace al poeta sentir y cantar asuntos desconocidos para sus contemporáneos. Una vez el poeta es poseedor de ella, un inspirado, se convierte en el mejor inventor. Dice Caro que cuando Dios creó a los hombres a su imagen y semejanza, les dio en esa instrucción el talento de la invención. Señala la labor del arquitecto y del filósofo como de invención menor en comparación a la labor del poeta, "en quien mejor se ve realizado el aserto bíblico". En palabras de Caro, Dios da al hombre alma y cuerpo, que son inseparables; hace igual el poeta, en cuya obra pensamiento y forma nacen juntos y no se pueden separar (p. 149). Además, mientras Dios crea al hombre de la tierra, le da vida y lo hace mortal, el poeta crea su obra, pone en ella sus "creencias, sentimientos y ficciones" y les da "una forma imperecedera". Dudo que Caro 
haya querido decir que el poeta se convierte, ayudado por Dios, en mejor inventor que Dios mismo; sin embargo, la comparación que plantea corre el riesgo de ser interpretada así.

También Sanín Cano habla de la inspiración, pero no la sitúa en las "miras providenciales" de Caro que ostentan un tinte religioso. Sanín Cano (1934) habla en "El milagro cotidiano" del orador cuya "palabra se convierte en un elemento de propulsión más fuerte a veces que el raciocinio y más tenaz que la voluntad" (p. 171). Dice que el cuerpo del orador vibra movido por la fuerza de una voluntad exterior, que lo maneja como a un saco vacío. Al final, el orador "sabe apenas lo que ha dicho. Ese poder inescrutable, que yacía en el fondo de su ser, lo ha dominado por instantes y ha hecho vibrar en su cerebro regiones que permanecen insensibles a otro género de excitaciones" ( $p$. 171). La imagen podría parecer romántica, si no se hablara de una "voluntad exterior". Al admitir que no es de la mente del orador de donde provienen las palabras y su articulación en un discurso fuera de lo común, Sanín Cano está apuntando a lo sobrenatural, a algo proveniente del exterior que bien podría identificarse con la gracia de Dios, aunque no reciba ese nombre.

Juan de Dios Uribe parece enfrentarse con la necesidad de nombrar eso que parece innombrable, además de oponerse a la creencia de que ese algo es dado por Dios. Así, se configura la imagen de la musa que se encuentra en sus estudios críticos. Para este autor, la musa se presenta de forma diferente a cada poeta. Las Musas de planta ligera dan "las primicias de sus amores a donceles garridos como Pombo" (Uribe, 2013, p. 319), por quienes son perseguidas y a quienes dictan "fugitivas confidencias". La musa de Diógenes Arrieta es enemiga del error y lo lastima cada que pasa cerca de él (p. 121), además suele manifestar su veneración por la verdad y es noble e intrépida. La musa de Uribe Velásquez, por su parte, es una "peregrina". Finalmente, la musa de Antonio José Restrepo es

[...] una aldeana que no ha perdido el vigor del campo en los refinamientos de las ciudades. No sufre achaques de mujeres. Sus cóleras son legítimas, su dolor sentido, su alegría verdadera y su risa franca. Es un talento sincero. El hombre sirve de garantía al poeta (p. 176).

Hasta este momento no hay nada que nos diga que estas musas provienen del interior o del exterior del poeta. Sin embargo, podría pensarse que, a pesar de que trabajan con el poeta buscando la verdad e inspirando su talento, no son un mismo ser. Estas musas parecen tener vida propia y un carácter diferente al de los poetas que acompañan. Esto se confirma en un texto de Uribe sobre Juan C. Tobón en el que, vaticinando las consecuencias 
que los vicios y las pasiones violentas tendrán en él, dice: “entonces las musas lo abandonarán y doblará la frente temprana en la oscuridad que apenas turbó un ligero resplandor" (p. 137). Las musas para el Indio Uribe son, entonces, figuras sobrenaturales que provienen del exterior y que bien pueden decidir cuándo marcharse.

De manera parecida configura Samper (1953) su idea de la musa. Por ejemplo, la musa de Gregorio Gutiérrez le inspiraba "alternativamente las endechas sentimentales y los más burlescos epigramas" (p. 140). Además, Samper encuentra que es diferente para cada quien cuando afirma que su musa es inferior en inspiración a la del "bardo antioqueño", pero no en lo tocante a la espontaneidad y fidelidad del sentimiento. Al hablar de Samper sí podría pensarse en una musa proveniente del interior, no solo porque este autor fuese profundamente romántico, sino también porque él mismo manifiesta que la musa cantaba su dolor. Ella conoce a Samper tan profundamente y logra expresar tan bien sus sentimientos, que resulta imposible pensar que no sea parte intrínseca e inseparable de él.

Por su parte, Silva habla de las musas en varias ocasiones. Dice de la musa de Baudelaire que fue incapaz de "defenderlo de la idea fija de la muerte" (Silva, 1888, n.p.). En la musa de Verlaine ve transformaciones que no obedecen a la calidad o al carácter de los versos del poeta. Ya en esto hay una pista de que la musa no corresponderá a la figura del poeta y de que viene de fuera. Para confirmar esto, basta echar un vistazo a una de sus prosas líricas titulada "La protesta de la Musa", publicada en 1891 en la Revista Literaria. En dicho texto, Silva sitúa al lector en el cuarto de trabajo de un poeta. De repente, en la habitación, que estaba sumida en la oscuridad, aparece la musa, "sonriente, blanca y grácil", de "ojos claros en que se reflejaba la inmensidad de los cielos" (Silva, 1891, p. 133), y empieza a hablar con el poeta sobre lo que él ha escrito: un libro de sátiras. Avergonzado, el poeta confiesa haber recibido su inspiración de las flechas de los Genios del odio y del ridículo. A continuación, interpela a la Musa y le critica su seriedad:

Tú nunca te ríes; mira, las flechas al clavarse herían, y los heridos hacían muecas risibles y contracciones dolorosas; he desnudado las almas y las he exhibido en su fealdad, he mostrado los ridículos ocultos, he abierto las heridas cerradas [...] y me he reído al hacer reír á los hombres, al ver que los hombres se ríen los unos de los otros. Musa, ríe conmigo (p. 133).

Pero la Musa, cada vez más contrariada, reclama al poeta por haber usado y profanado las formas sagradas en un innoble propósito. Lo reprende 
por haber removido el cieno y el fango en vez de las piedras preciosas, "de los esmaltes policromos y de los camafeos delicados, de las filigranas áureas, $[\ldots]$ de los encajes que parecen tejidos por las hadas" (p. 134). La musa expone su odio por los reptiles que habitan en los pantanos y se declara amiga de los "pájaros, de los seres alados que cruzan el cielo entre la luz" (p. 134) y a los que inspira cuando dan serenatas. Pero su carácter es mucho más fuerte:

Yo he sido también la Musa inspiradora de las estrofas que azotan como látigos y de las estrofas que queman como hierros candentes; yo soy la musa Indignación que les dictó sus versos á Juvenal y al Dante; yo inspiro á los Tirteos eternos; yo le enseñé a Hugo á dar los alejandrinos de los Castigos [...] Pero no conozco los insultos ni el odio (p. 134).

Después de revelarse en toda su grandeza, abandona al poeta para siempre y le dicta su sentencia: "Jamás me sentirás cerca para dictarte una estrofa". El poeta queda sollozando y allí termina el texto. Esta musa viene, en efecto, del exterior del poeta, es sobrenatural. Sin embargo, es la Musa, y en esto se diferencia de las musas de Uribe. Cuando la Musa habla de sus trabajos pasados con Dante, Hugo y Juvenal, queda claro que ella es la única, que no había una musa personal para cada uno, sino que ella misma los guiaba a todos. Incluso podría pensarse que es la Musa a la que cantaban Homero y Virgilio.

Una vez las musas han inspirado a sus poetas, les han dictado los versos o les han maravillado con su soplo fresco, está lista la obra. Ella mantiene en sí la magia por la que fue concebida. Así lo notan también Uribe y Silva. Para Uribe (2013), un libro de poesías es "un dulce refugio para los espíritus delicados [...] si las notas son suaves, llegan como una bocanada de aire puro y fresco; cuando hierve la pasión allí el cerebro se enciende, pero entre acordes de música grave" (p. 295), por eso este autor se atreve a decir que la poesía es la aureola en la cabeza de los hombres que se confunde con un milagro. Para Silva (1893), un libro es lo que para Anatole France: un "aparatico mágico que lo transporta a uno en medio de las imágenes del pasado, o entre sombras sobrenaturales" (n.p.), el producto del sortilegio del arte. Milagro o magia, ambos escritores están pensando en el poeta y en su obra como productos de lo sobrenatural, de lo fantástico.

Así, de un lado la imaginación orgánica y del otro la sobrenatural funcionan como ejes que unifican el ejercicio crítico de los escritores estudiados, por encima de las diferencias que cada uno presenta. Ambas imaginaciones, como vimos, se relacionan con dos propuestas culturales, 
sociales y políticas que se encontraban en disputa en el siglo XIX y cuya tensión, viva todavía hoy, aunque en formas distintas, respondía a un problema mayor: el de la pertinencia de mantener una nación tradicionalista o, por el contrario, de sentar las bases de un programa que abogase por la secularización, el cambio y la autonomía. Lo interesante es que en los textos de los que traté no se percibe una intención meramente facciosa, sino, sobre todo, una especie de hibridación, de prolongación de la tensión que llena de riqueza y matices a la crítica colombiana naciente. Aun hay otros tipos de imágenes que podrían abordarse en una nueva investigación y que dirían mucho más sobre este problema y sobre otros. Especialmente, llaman la atención las imágenes que usan los autores para hablar de las razones por las que perdura una obra o por las que una llama más la atención que otra. Valdría la pena continuar estas investigaciones que pueden acercarnos más al análisis del desarrollo de una de las ramas más importantes de los estudios literarios, y permitirnos sentar unas bases sólidas para la comprensión de la evolución del género crítico y del pensamiento colombiano hasta nuestros días.

\section{Referencias bibliográficas}

1. Arango, S. y Fernández, C. (2011). Fundamentos estéticos de la crítica literaria en Colombia. Finales del siglo XIX y comienzos del siglo XX. Medellín: Editorial Universidad de Antioquia.

2. Aullón de Haro, P. (1994). Epistemología de la teoría y la crítica de la literatura. En Teoría de la crítica literaria (pp. 11-26). Madrid: Trotta.

3. Caro, M. A. (1951a). Bastiat y Bentham. En Artículos y discursos (pp. 79-110). Bogotá: Biblioteca Popular de Cultura Colombiana.

4. Caro, M. A. (1951b). La religión y la poesía. En Artículos y discursos (pp. 367-392). Bogotá: Biblioteca Popular de Cultura Colombiana.

5. Caro, M. A. (1985). Estudios Virgilianos. Primera Serie. Bogotá: Instituto Caro y Cuervo.

6. González Echevarría, R. (1998). Mito y archivo. Una teoría de la narrativa latinoamericana. México: Fondo de Cultura Económica.

7. Jiménez, D. (2009). Historia de la crítica literaria en Colombia. 1850-1950.Bogotá: Universidad Nacional de Colombia.

8. Samper, J. M. (1953). Selección de estudios. Bogotá: Biblioteca de Autores Colombianos.

9. Sanín Cano, B. (1890). Del estilo. Revista Literaria 1 (7), pp. 10-26.

10. Sanín Cano, B. (1934). Divagaciones filológicas y apólogos literarios. Manizales: A. Zapata.

11. Sanín Cano, B. (1944). Letras colombianas. México: Fondo de Cultura Económica. 
12. Sanín Cano, B. (2013). El Indio. En J. de D. Uribe. Obras completas (Parte II) (pp. 41-48). Medellín: Instituto Tecnológico Metropolitano.

13. Silva, J. A. (1888|2018). Crítica ligera. En R. Mataix (Ed). Escritos de crítica literaria. Biblioteca Virtual Miguel de Cervantes. Disponible en https://bit.ly/2B15Drw [10.09.17].

14. Silva, J. A. (1891). La protesta de la musa. Revista Literaria 1 (9), pp. 133-135.

15. Silva, J. A. (1893|2018). El cofre de nácar, por Anatole France. Noticia biográfica y literaria. En R. Mataix (Ed). Escritos de crítica literaria. Biblioteca Virtual Miguel de Cervantes. Disponible en https://bit.ly/2B15Drw [10.09.17].

16. Silva, J. A. (1894|2018). Rubén Darío. Noticia literaria. En R. Mataix (Ed). Escritos de critica literaria. Biblioteca Virtual Miguel de Cervantes. Disponible en https://bit. ly/2B15Drw [10.09.17].

17. Uribe, J. de D. (2013). Obras completas (Parte II). Medellín: Instituto Tecnológico Metropolitano. 